\title{
Transnationalism and expatriate political engagement: The case of the Italian and French voting in Australia
}

\author{
Dr Maryse Helbert
}

Maryse joined Melbourne University and completed her $\mathrm{PhD}$ in international Relations and Political Economy in 2016. Prior to that, she was an advocate for and research on women's participation in politics and decision-making for over a decade. She is now focusing on teaching and research in the fields of political Science and International Relations.

Assoc. Professor Bruno Mascitelli

Swinburne University of Technology, Melbourne

Prior to joining Swinburne University of Technology, Bruno was employed by the Australian Consulate in Milan, Italy where he spent 18 years. In 1997 he joined Swinburne University and has since focused his teaching and research in areas related to European Studies. This has included four books on Italy and its expatriate community abroad looking at expatriate voting in particular. He is President of the European Studies Association in Australia.

\section{Abstract}

The aim of this paper is to provide an appreciation and analysis of the expatriate connectivity of Italian and the French citizens from their place of residency in Australia through their respective elections in their home country election. Specifically, the paper will examine the cases of Italians in Australia voting in the 2013 Italian elections and equally that of French citizens in Australia voting in the French Presidential and the following Legislative Elections in $2017^{1}$. The paper examines the voting patterns there might be between those voting in the home country (Italy and France) and those voting in external electoral colleges in this case the relevant Australian college. This paper shows that those living abroad, in this case Australia provide different political choices and less surprising low voting participation compared to the domestic districts. It equally highlights that the transnational community can be and is influenced by the political context of their host country which will be different from that which occurs in the home country.

\footnotetext{
${ }^{1}$ The paper was unable to discuss the Italian March 2018 election given that the paper was mostly prepared before that election results were released.
} 


\section{Introduction}

In association with ongoing migration movements globally, transnationalism and expatriate political engagement has become a more common feature in our global political activity than ever before. While in many countries, there is a tightening up of migration eligibility criteria for incoming migrants (Mares 2016), ironically there has also been an expansion of dual (and multiple) nationality access and even in some cases access to citizenship based on jiu solis. At the same time, many nations have gone from being emigration nations to a hybrid of both emigration and immigration simultaneously such as Italy. Besides the "normal” patterns of migration, if such a term can be used, we are also witnessing new migration patterns, which are impacted by war, misery, repression, political discrimination and more recently by climate change as the film "30 million” graphically illustrates. Adding to this complexity is the ability of these new migrations to communicate quickly and promptly through social media and other instantaneous forms of communication. The rise of social media, 24-hour media coverage and website-wifi information availability is telling many of where to go and how to go about it. Migration movement continues to be a key feature of evolving demographic makeup of nations and over time, nations and their political and democratic structures have been built from this human pool as a result of migration. Since the 1980s, a number of migration approaches have been discussed by scholars to better understand the drivers of this movement but as one scholar noted migration is complex and few models have provided sufficient understanding to allow a one type fits all (King 2012).

With large migration movements across many parts of the globe we are also evidencing greater levels of incidents of expatriate engagement either of high profile or less so. In other cases where large numbers of emigrants from countries emigrant community organisations have sought to lobby their home country to seek out representation or at least have their issues addressed in the home government. At work in these scenarios is the voice and role of expatriate communities in home politics.

The aim of this paper is to provide an appreciation of the expatriate connectivity of Italian and the French citizens through their respective elections and how these two communities responded politically in their elections from Australia. Specifically the paper will examine the cases of Italians in Australia voting in the 2013 Italian elections and equally that of French citizens in Australia voting in the French Presidential and Legislative Elections May 2017. The Italian referendum of December 2016 was not a useful comparative example as the political behaviour around referendums work very differently and fail to meet a comparative equation and therefore could distort the comparison. Equally the Italian March 2018 elections 
occurred soon after the completion of this paper and therefore is not considered in this analysis. The paper will examine the voting patterns there might be between those voting in the home country (Italy and France) and those voting in external electoral colleges in this case the relevant Australian college. What do these voting patterns tells, what are the consequences of this vote in the two jurisdictions and what does it say for democracy both in the home country as well as in the host country? For purposes of clarity and simplicity Italians in Australia will be referred to as Italian-Australians and the same will apply to the French-Australians.

\section{Transnationalism at the heart of expatriate political engagement}

Transnationalism is when populations migrate to another country to settle and simultaneously seek out ongoing connections with their home country (IOM 2010). Moreover, migrants make major sacrifices and investment in keeping an involvement in the activities of their home country including travel to and from their original home (Portes 1999). These engagement activities have ranged from return remittances, economic support, investment and family welfare. The activity that most interests this paper is that of political transnationalism.

The legitimacy of the inclusion of non-resident citizens in elections of their countries of origin has been debated for years (Lafleur 2008). According to Bauböck (2007) involving expatriates into the political life of their homeland is one of the possible ways by which countries can include minorities living far from their country of origin. Most of the time, the political engagement of migrants has been supported and justified especially for first generation of migrants who relocate in a foreign country (Rubio Marin 2006).

The engagement of transnational communities (and therefore former migrants) in the political life of their country of origin has become a common electoral practice around the world. In the last count of such an activity, more than 120 countries implemented expatriate voting policies in one form or another worldwide (IDEA \& IFE Report 2007). The involvement of expatriates in the political life of their homelands has been considered a crucial strategy of expanding and nurturing the connection and the sense of belonging of migrants and their descendants living outside their homeland borders (Vertovec 2004). This practice has been also defined a strategy for the diaspora integration implemented by countries that have been affected by migration waves.

In the European Union, these include nations such as Croatia, France, Italy, Portugal and Romania, which have created what have been defined "foreign constituencies" (Hutchenson \& Arrighi 2014). Within these constituencies, migrants can vote their own representatives in the homeland parliament. The presumption is that this representation is to 
serve the interests of the transnational communities in their home countries. Among these EU states, the expatriate voting system in Italy is the most far-reaching and as such the most controversial. The 2001 inclusion of Italian citizens abroad in the electoral process with the creation of the foreign constituency has become, though not originally intended, a 'game changer' after its first implementation in the 2006 Italian election.

Much research has been conducted to provide both a normative and empirical discussion of the phenomenon of political transnationalism (Barry, 2006; Bauböck 2007). The assumption in this paper is that nation-states foster the connection with migrants for specific and idiosyncratic domestic political reasons. Key to the theme of this paper is the question of whether political engagement with the expatriate community is one seeking genuine interest towards the political inclusion of transnational communities abroad. This may not always be evident.

The arguments used to support the extension of the enfranchisement of external citizens living abroad are different. A first motivation for the implementation of expatriate voting policies is the economic contribution migrants give to counties of origin by sending financial support to their family at home. Secondly, since many migrants relocate due to circumstances and against their will, for instance during and after conflicts, countries feel obliged to maintain connections with citizens abroad. Thirdly, migrants, especially the first generation of migrants, demonstrate to maintain strong connections with the homeland through the language, their culture and family. The cultural ties most of the time include great interest of migrants towards the political life of their home country. For this reason, cultural connections largely contribute in the debate in favour of the political engagement of migrants.

Migrants' involvement from an economic perspective appears to be one of the stronger reasons to support the legitimacy of political participation of citizens living abroad. Sending countries often require citizens residing abroad to pay taxes in their country of origin. In these circumstances, migrants are legitimised to have a saying in political future of a country in which they do not reside anymore but with which they still have economic connections (Lopez Guerra 2005). However, the economic reasons alone are not entirely convincing. According to Rubio Marin (2006) migrants should be interested and aware of homeland political events in order to participate responsibly during the election since their votes can influence the political outcome of the country of origin.

\section{Political transnationalism}


There are different reasons for the extension of the enfranchisement to citizens living outside national borders. The political engagement of migrants has frequently been supported and justified for first generation of migrants who relocate to a foreign country (Rubio Marin 2006). However, there are numerous motivations that foster the inclusion of emigrants in the political life of the country of origin. A first motivation is the economic contribution migrants make to the country of origin, sending remittances to support their families at home. Secondly, citizens living abroad can be included in the electoral process if they have experienced forced migration and they had to relocate often against their will. Thirdly citizens, especially first generation emigrants, usually maintain a strong connection with their homeland due to their language, culture and family connections. This interest can also include political interest in the events in the country of origin.

Engaging emigrants from an economic perspective is one of the main reasons why emigrants are also included in the electoral system of the country of origin (Lopez Guerra 2005). Citizens living abroad can be impacted by taxation commitments from the country of origin. Even though they do not reside in their home country any longer, they may still be in possession of a previous residence or other related property, which the sending country may require fiscal returns from. However, states allowing expatriates to participate in the political life of their home countries should not be solely due to economic factors. Citizens living abroad should also share a degree of interest towards the political affairs of the sending country in order to participate responsibly (Rubio Marin 2006).

The implementation of expatriate policies has raised the question whether migrants should be entitled to interfere in electoral outcomes and governance of nation-states in which they do not reside. In some cases, migrants are invited to participate in the political life of their homeland supporting political parties’ campaigns abroad (Barry 2006). Despite some level of political engagement from abroad, it has been argued that migrants should not be included in the political election system of their country of origin because they will never be affected by the decisions made by the government since they no longer live in that country and reside elsewhere (Rubio Marin 2006).

Despite the criticism towards the political inclusion of non-resident citizens, these policies have found significant support among national political parties. According to Bauböck (2009), political parties are the first stakeholders in maintaining a connection between migrants and their homeland. Homeland political parties have established external offices in the hosting countries, associations based on their area of origin (e.g. regional clubs) and have developed strong networks among migrants. The aim of these networks is to lobby their home government 
and influence them in the decision making process about matters that can affect transnational communities such as citizenship and the expatriate vote (Portes 1999).

Expatriate voting and political engagement throughout the world is becoming a more common activity and more widespread than might initially appear. According to the IDEA (2013), more than 150 countries have some form of expatriate voting system allowing citizens of a home country to vote in domestic elections and forms of political representation. While many of the activities of newly migrated communities will be economic often in support of family who have not migrated and therefore the recipient of remittances and other economic support activities, as the newly migrated person settles in their home, for temporary or permanent basis, political contact slowly emerges and is developed.

Both Italian and French expatriate communities abroad have developed stable forms of political engagement for their citizens abroad over the last decades. Alongside political systems allowing for engagement there are also organisations of emigrant bodies which act as conduits and lobbies for the home country.

\section{Expatriate voting around the world: The case of Italy}

As a background note to the Italian case of expatriate voting, the Italian Constitution of 1948 noted the right of all Italians, irrespective of their location or residency, the right to participate in Italian elections in Italy. As such, in 2001 after many decades of debating and stalling, and a need to change the constitution to allow Italians abroad to participate in elections, the Italian government passed a law permitting expatriate voting and representation. This very elaborate system allowed for Italians abroad voting for their own representatives across four large external colleges. These external colleges representing Europe, North America, South America and Asia-Africa-Oceania and Antarctica (rest of the world) would account for 12 House of Deputy representatives and six senators who sit in the Italian Parliament and vote generally with their political colleagues in Italy for Italian legislation. This includes voting for government majorities when this is called for. No other country in the world developed such an elaborate political system of representation for its expatriates as this one. However, this system is not without its detractors and controversy (Mascitelli et al. 2013).

The structure of the external colleges has borne much criticism due to their size and geographical coverage. Some of these geographical districts have an enormous territory to cover and for this reason, the representation of Italians living abroad can be both inefficient and unfair. As electoral results confirmed, due to the large presence of Italians in Australia, the representatives for the AAOA district will most likely come from Australia, leaving Italians 
residing in Africa and Asia with no representatives coming from these parts of the world (Mascitelli \& Battiston 2008).

Another area of concern is the manner in which the vote is conducted meaning the system of voting by correspondence. The fact that voters cast their vote by correspondence rather than at ballot stations is considered by some to be of concern because of the potential abuse and interference, which can take place. The voting by correspondence does not provide any certainty about the identity of the voter. The fact that the secrecy and personality of the vote are criteria that are not guaranteed by the mailing system has been identified as an issue which violates the principles of the Italian Constitution. In order to address the issue of the privacy of voting on election day, polling stations should be created at Embassies and Consulates where Italian citizens can cast their vote in person.

While there are many strands of debate on why and how Italians around the world will take part in Italian elections the decades long controversy was eventually realised in its first real test in 2006 when Italy conducted its first election involving Italians abroad. The result was immediately shrouded in controversy as Silvio Berlusconi the leader of the centre-right government, lost the elections by a handful of votes. Indirectly this defeat was partially as a result of the poor showing abroad throughout the expatriate community. While Berlusconi expressed his fury against the expatriate community for its electoral behaviour (not voting for his party), the result provided an initial red flag in which the expatriate community behaved very different politically to the manner in which the Italians voted in Italy (Battiston \& Mascitelli 2008). The elections in 2008 and again in 2013 showed in various facets that the electoral behaviour of expatriates abroad was somewhat different to that in Italy often voting in complete contrast than the Italians in Italy voted.

The Italian expatriate law of 2001 was approved by an overwhelming majority of the Parliament at the time. The opposition to this legislation was only expressed from the extremes of the political spectrum - the far right and the far left. The real concern with legislation occurred when it was realised that there had been an under-estimation of the impact of the expatriate vote and that it could be a "game changer". It was never intended to have this political impact. It was only after the first election in 2006 that the seriousness of this initiative emerged and some policy makers as well as legal authorities began to see serious omissions in this implemented legislation. One of Italy’s most reputable political scientists, Giovanni Sartori (2004) realised the error in the legislation and said so. He defined the legislation and its practical implementation as a "foolish and senseless" project (Sartori 2004). Because of the 
lengthy and complex method of introducing the law, the manner of changing the law would be equally as laborious.

Other criticisms have been in relation to the impact of votes on the electoral results. Votes coming from overseas were never conceived to be influential in the count to determine the majority in parliament and votes collected in the foreign constituency were considered separately with no direct implication on the electoral outcomes (Vigevani 2002). Furthermore, the voting system in the foreign constituency is different compared to the voting system used in the Italian electoral law for domestic districts. While in Italy, the electoral law followed the first-past-the-post system, in the foreign constituency the system is based on the proportional representation system. Some concerns about the representation methods were brought to the attention of the Parliament from the MP Boato who stated that expatriate voting policy goes against the electoral rights of equality promoted by the Italian Constitution. The foreign constituency, together with the limitations for candidates based on the residency principle, are the two key elements that makes this law unique within the Italian context and around the world (Tarli Barbieri 2007).

A matter of practical significance when discussing expatriate voting is the freedom to engage in the distribution of electoral propaganda as well as the way in which voting is conducted. These matters acquire greater attention when one considers that voting and propaganda circulation is occurring on the soil of a host country. In the case of Italy, this matter alone caused great tension when Italian authorities discussed the practicalities of Italians voting in Italian elections especially in the case of Australia and Canada whereby these countries had a large presence of Italian citizens on their soil and were concerned about the violation of their sovereignty (Mascitelli et al. 2013). Australia and Canada, for instance, initially did not support Italian expatriate voting policy because they were concerned about the spill over into their societies of political squabbles originating from a nation far away. For this reason, Italy in the case of Canada was obliged to accept the restrictive conditions laid down by the Canadian government, which forbid public meetings and only permitted voting through correspondence. The consequences of these restrictions showed up the differences between the electoral systems implemented for the domestic electorate and that for the foreign constituency, which were unable to offer the same conditions and political access.

\section{The 2013 and 2008 Italian elections and the expatriate vote from Italian-Australians}

The election results from the Africa, Asia, Oceania and Antarctica college which is where Australia is located, provided a different set of electoral results from that which resulted in 
Italy. In the elections of 2013 for example the Mario Monti, who had been caretaker prime Minister in Italy for most of 2012 with his coalition called "With Monti for Italy” polled only 11 per cent in Italy while in the Australian college (AAOA) he polled double that figure (28.96 per cent). In addition, in 2015 the Five Star Movement in Italy polled 25.5 per cent while in the Australian college (AAOA) it only polled 15 per cent of the vote.

Table 1: 2013 elections - House of Deputies results for the external college Africa, Asia, Oceania and Antarctica (AAOA)

\begin{tabular}{|l|l|l|l|}
\hline Party or Electoral Coalition & Total number of vote & \% of vote & Seats allocated \\
\hline Democratic Party & 14,741 & 33.16 & 1 \\
\hline With Monti for Italy & 12,872 & 28.96 & - \\
\hline People for Freedom Party & 10,103 & 22.73 & - \\
\hline Five Star Movement & 6,728 & 15.13 & \\
\hline Electoral turnout & & 30.01 & \\
\hline
\end{tabular}

Source: http://elezionistorico.interno.gov.it/index.php?tpel=C\&dtel=24/02/2013\&tpa=E\&tpe=-

A\&lev $0=0 \&$ levsut $0=0 \&$ es $0=S \& m s=S$

Similar trends and contrast between the Italian election vote in Italy as opposed to that in the Australian electoral college AAOA can be said about the 2008 elections though not as extreme. In 2008, the Five Star Movement did not exist. On the other hand, the Berlusconi People for Freedom Party received a 37 per cent vote in Italy but 43 per cent vote in the AAOA.

Table 2: 2008 election - House of Deputies results for the external college Africa, Asia, Oceania and Antarctica (AAOA)

\begin{tabular}{|l|l|l|l|}
\hline Party or Electoral Coalition & Total number of vote & \% of vote & Seats allocated \\
\hline Democratic Party & 21.295 & 44.66 & 1 \\
\hline People for Freedom Party & 20,533 & 43.06 & - \\
\hline Union of the Centre & 3,027 & 6.34 & - \\
\hline The Rainbow left & 1,717 & 3.6 & - \\
\hline Socialist party & 1,110 & 2.32 & - \\
\hline Electoral turnout & & 37.91 & \\
\hline
\end{tabular}

Source: http://elezionistorico.interno.gov.it/index.php?tpel=C\&dtel=24/02/2013\&tpa=E\&tpe=-

A\&lev $0=0 \&$ levsut $0=0 \&$ es $0=S \& m s=S$ 
The reasons for these discrepancies of differences are many. In some cases, the elections are primarily decided by the personalities standing. This is especially the case in the external colleges where the personalities have a far more intimate relationship with their voters irrespective of the party they are standing for. The role of the media in external voting can create some level of difference as noted by the Australian media support for Mario Monti (thereby bringing more votes to his coalition) and the Australian media negative view of Berlusconi resulting in lower levels of support for Berlusconi's coalition in the Australian electorate (AAOA). However, these reasons are anecdotal and speculative and would be required to undergo stronger and validated evidence observation.

\section{Expatriate voting: The case of France}

With 1.3 million expatriate voters registered in 2012 - the same electoral weight as Paris (Béglé 2017) - the French government has tried over the years to capture the political attention of expatriates, albeit with little success and at a very high cost. Harnessing the voting power of French expatriates and their political engagement in France has been an issue since the Revolution. At first, the issue was about the status and democratic representation of French citizens living either in French colonies or foreign countries. Later, the government saw French expatriates as an asset for promoting French culture abroad, but also a geopolitical stake due to the increasing number of French citizens living abroad (Le Luyer 2016, Ricout 1999). In December 2008, there were 1,428,046 persons on the French Citizen Living Abroad Register while in December 2017 there were 1,821,519 in 168 countries - an average annual increase of 3.24\% (Brennetot, Colange 2009, France Diplomatie 2017).

It was in 1949 that expatriates were granted the right to vote for Senators. Three seats out of the 230 members of the Senate (then called le Conseil de la République) represented the rest of the world, divided into three parts; Europe, America and Asia-Oceania (Assemblée des Français de l'Etranger 2009, Collard 2013). These three senators are elected through the electoral college of the High Council of French Citizens Living Abroad (Conseil Supérieur des Français de l'Etranger, CFSE). Created in 1948, the High Council was composed of the 55 members where eight seats and 42 seats were, respectively, attributed to the heads and elected representatives of four organisations representing the interests of French citizens abroad: l'Union des Chambres de Commerce Françaises à l'Etranger, la Fédération des Anciens Combattants, l'Union des Français de l'Etranger. An additional five members of the Council were appointed by the Foreign Minister (Assemblée des Français de l’Etranger 2009). 
The CSFE had three main tasks, which were aimed at harnessing the French patriotism of the expatriate population. First, it had to organise the election of the three Senators through its electoral college (Loi Organique 76-97 1976). Second, a register was opened for expatriates since it became a requirement to either register or be a member of one of the organisations representing the interests of French citizens abroad (mentioned above) in order to vote. This register was also used to better understand the expatriate population. A final role of the CSFE was to take charge of the government's duty of care for expatriates, on issues such as school fees, tax and inheritance.

However, the CSFE was criticised for being far too sympathetic to right leaning parties as all its senators were right-leaning candidates (Collard 2013, 217). These criticisms were further fuelled by the then President Valéry Giscard D’Estaing granting expatriates the right to vote for the European, Presidential Elections and Referendums. The expanded voting rights were granted and Valéry Giscard d'Estaing understood expatriates vote could be an asset for his right leaning party during election times (Collard 2013, 217). This was confirmed during the Presidential Elections in 1981, where the Socialist candidate, Francois Mitterrand, won 51 per cent of the votes on the French territory and became president, but expatriate votes overwhelmingly favoured Valéry Giscard d'Estaing with $69 \%$ of the votes. To counter this voting trend, the Parti Socialiste decided to create another organisation called Association Démocratique des Français à l'Etranger (ADFE) to support the left leaning views of expatriates (Collard 2013, 217).

However, the additional rights that expatriates were granted did not reverse declining voting participation. Indeed, in the Presidential Election in 1981, $75.3 \%$ of the 132059 registered voters voted, while in 2002, only 37.3 \% of the 385537 registered voters voted (Le Luyer 2016, 277, Assemblée Nationale 2014).

This led the French government to implement two major pieces of legislation to boost 'the nationalist and European sentiment of the two million French citizens living abroad' (Garriaud-Maylam et al. 2002). In 2003, the first piece of legislation increased the number of Senators to twelve, elected for six years, with half renewed every three years. A new entity called the 'Assembly of French citizens abroad' (Assemblée des Français de l'Etranger, AFE) was created to replace the former High Council. The 90 councillors of the AFE would form the electoral college for the indirect election of twelve senators in a single constituency (Assemblée des Français de l'Etranger 2009). The members of the AFE are directly elected by the 443 Councillors of Consulate Councils, created in each French embassy or consulate across the 
world. The 443 councillors are elected for six years in 130 constituencies and have an advisory role (Assemblée des Français de l’Etranger 2009).

The second major piece of legislation in 2008 granted French citizens living abroad the right to elect representatives in the lower house (called 'Deputies') and have the same bicameral representation as citizens living in France. Eleven, out of a total of 577 Deputy representatives would sit in the National Assembly (Assemblée Nationale) and represent the rest of the world, divided into 11 constituencies. The 11th constituency is South Asia-Oceania, made up of 49 countries of the Middle East, South Asia and Oceania. Australia is part of this constituency and, as at the 2017 elections, had seven voting stations for the Presidential and Legislative Elections (Loi organique no 2013-659 du 22 Juillet 2013).

However, the reforms of 2003 and 2008 did not overcome all the major hurdles they were designed to address. Indeed, an extended right to vote did not dramatically boost participation for any elections. While voting participation for the Presidential Elections (second round) between 2007 and 2017 increased from 40.3\% in 2007 to 45.84\% in 2017, voting participation for the Legislative Election actually declined for the second round, from $20 \%$ in 2012 to 18\% in 2017 (Ministère de l'Intérieur 2017). It can also be argued that the spike in voting participation in 2017 Presidential Election was due to the predicted qualification of a National Front candidate in the second round which attracted large media attention around the world which could have mobilised voters (BuzzFeed, 2017). Despite the spike, the low voting participation shows a gap between the French government's will to politically engage expatriates, and the timid response of expatriates when voting.

Nor did the reform which created the new entity, AFE, ease criticism of its political bias and of it being 'a tool of electoral propaganda' for the right-leaning party (Dehesdin and Pottier 2011). According to the opposition (the left party), during the 2008 reforms, population increase and distribution were not the real priority of the boundary design for the 11 constituencies. Rather, the opposition accused the right-wing government in place of gerrymandering electoral boundaries to create safe seats. The government was also criticised for choosing an electoral system, that is the two-party majority electoral system, that would favour the right-wing leaning party (Dehesdin and Pottier 2011).

These criticisms were partially confirmed in the following Presidential Elections, although with a smaller margin than prior to the 2008 reforms (Table 3). In 2012, Nicolas Sarkozy, a right-leaning candidate won in the second round against Segolene Royal, a leftleaning candidate, by a margin of 7 points (table 3). In 2017, Emmanuel Macron won by a margin of 78 points. 
While Expatriates tend to vote for a right-leaning candidate, they reject the extremeright candidate. Both the 2002 and 2017 Presidential Elections showed that expatriates rejected extreme-right candidates when they make it through to the second round. In the 2017 Presidential Election, Macron, the 'En Marche’ candidate, was facing, and won against, Marine Le Pen, the National Front candidate (Cavagna 2017). In the 2002 Presidential Election, Jacques Chirac, a right-wing leaning candidate, also faced a National Front candidate (Jean Marie Le Pen). Le Pen also lost the election by a large margin, on French territory and abroad. In both cases expatriates overwhelmingly rejected the National Front candidate to a greater degree than their territorially-based compatriots.

However, while the Presidential Elections in 2017 was particular as it involved a National Front candidate, it does not entirely discount the hypothesis of an expatriate voting pattern toward a right leaning candidate. Although it is very difficult to place Macron, the new president, on the political spectrum, as he has declared himself and his party 'En Marche' as being neither left nor right, there are still clues which substantiate the case for him being more right-leaning than left. Macron's place on the political spectrum, his Presidential campaign, policy program, his accession to the presidency have dramatically changed the political landscape. This change has been compared to the Presidential campaign and election of President Valéry Giscard d'Estaing, a right-leaning candidate (De Saint Sauveur 2017). Quatremer claims that Macron is on the right of Valéry Giscard d'Estaing, particularly in matters of social policy and security issues (2017). If we accept this hypothesis, then expatriates' right-leaning views are confirmed by the result of the second round of the Presidential Election where Macron won 89.31 per cent of the expatriate votes (89.07 per cent in Australia) (Ministère de l'Intérieur 2017) - significantly more than the 66.1 per cent won in the general France itself (Table 3).

Table 3: Results Presidential Elections, Second Round, 2007, 2012 and 2017

\begin{tabular}{|l|l|c|c|c|}
\hline \multicolumn{2}{|c|}{ Presidential Election 2007 } & Australia & The world & France \\
\hline & Voters turnout (\%) & 36.3 & 42.13 & 83.97 \\
\cline { 2 - 5 } & Sarkozy (\%) & 55 & 54 & 53.06 \\
\cline { 2 - 5 } & Royale (\%) & 45 & 46 & 46.94 \\
\cline { 2 - 5 } & Number of voters & 3565 & 346310 & 36.7 million \\
\hline
\end{tabular}

\begin{tabular}{|l|l|c|c|c|}
\hline \multicolumn{2}{|c|}{ Presidential Election 2012 } & Australia & The world & France \\
\hline \multirow{2}{*}{} & Voters turnout (\%) & 36.5 & 42.18 & 80.35 \\
\cline { 2 - 5 } & Sarkozy (\%) & 57.08 & 57.55 & 48.36 \\
\cline { 2 - 5 } & Hollande (\%) & 42.92 & 42.45 & 51.64 \\
\hline
\end{tabular}




\begin{tabular}{|l|l|c|c|c|}
\hline \multicolumn{2}{|c|}{ Presidential Election 2017 } & Australia & The world & France \\
\hline \multirow{2}{*}{} & Voters turnout (\%) & 51.37 & 45.84 & 75.34 \\
\cline { 2 - 5 } & Macron (\%) & 89.07 & 89.31 & 66.1 \\
\cline { 2 - 5 } & Le Pen (\%) & 10.63 & 10.69 & 33.9 \\
\cline { 2 - 5 } & Number of voters & 8076 & 579954 & 31 million \\
\hline
\end{tabular}

Source: www.interieur.gouv.fr/Elections/Les-resultats/Presidentielles/elecresult_presidentielle2017/(path)/presidentielle-2017/FE.html

While Presidential Elections have had similar voting patterns over the years, Legislative Elections have seen several patterns emerging. First, and as on French territory, there is a large difference in voter participation between Presidential and Legislative Elections, where French voters systematically favour Presidential Elections. There is also a declining voting participation on French territory. While expatriate votes are consistently lower in percentage terms than those on French territory, they follow similar voting patterns, and in a more acute way. In 2012, voter turnout for the Presidential Election on French territory was 79 per cent while for the Legislative Election, it was 73 per cent (Ministère de l'Intérieur 2017). In 2017, voter turnout for the second round of the Presidential, was exceptionally low at 74 per cent, while for the Legislative it was 59 per cent, a record low on French Territory. In the same elections, French citizens living abroad similarly favoured Presidential over Legislative Elections (Ministère de l'Intérieur 2017). In 2012, participation by expatriates at the Presidential was 42 per cent while for the Legislative, it was 20.5 per cent. In 2017, voter turnout was 45.84 per cent for the Presidential Elections and only 18 per cent for the Legislatives (Ministère de l'Intérieur 2017). Overall, there has been an increasing number of voters, on French territory and abroad, who have stopped voting, and the difference in participation between the Presidential and Legislative Elections has increased over the years.

Second, the criticism that right-wing party in power in 2008 had gerrymandered eleven constituency boundaries in their favour did not translate into reality in the 2012 Legislative Elections. Despite polls in 2012 which predicted victory for the UMP in nine out of the 11 new constituencies, the UMP obtained only four in the Legislative Elections of 2012 (Ministère de l’Intérieur 2018).

However, the 2017 Legislative Elections confirmed the long-term expatriates right leaning vote pattern. In the 2017 Legislative Elections, candidates affiliated with Macron’s 
party 'En Marche' won 8 out of the 11 constituencies and the traditional right-wing party did not win any (Ministère de l’Intérieur 2017).

Third, very low participation, particularly among expatriates in the Legislative Elections, has sparked debate about both the cost of organising such elections (and the political legitimacy of subsequently elected deputies, discussed below). Organising elections for expatriates is very expensive compared to elections on French territory. In 2017, the Cour des Comptes published a report showing that between 2011 and 2014, the cost of organising elections abroad was €34 million (Cour des Comptes 2017). In 2012 alone, the combined cost of organising the Presidential and Legislative Elections abroad was €20.6 million. The same year, it was calculated that the average cost per voter on French territory was $€ 7.45$ while the average cost per expatriate was $€ 20.5$ (Cour des Comptes 2017). The report provided recommendations to decrease the cost of organising elections abroad. It recommended a transition to paper-free campaigns and elections. Many voters had previously complained about the overwhelming number of documents received from political parties and candidates by mail, often long after the elections themselves were over (Roudin 2017).

The report also acknowledged the deterrent effect of a low number of voting stations combined with long distances that some voters had to cover in order to vote, especially in Australia (Cour des Comptes 2017). For instance, the entire state of Western Australia is served by a single voting station, despite it being 4 times the size of France.

The Cour des Comptes also recommended implementing mechanisms to avoid fraud during the electronic voting process, including through keeping better track of expatriates on the register, given that, in 2012, 20-30 000 voters on the register were no longer expatriates (Cour des Comptes 2017).

Finally, very low voter participation for Legislative Elections has raised significant concerns about the legitimacy deficit of the deputies of the 11 constituencies. The voter turnout for the Legislative Election in the second round for the $11^{\text {th }}$ constituency (comprising Australia) was 26\% in 2012 and only 22.6\% in 2017 (Ministère de l’Intérieur 2017). In 2012, Thierry Mariani - a right-wing candidate - won with only 10390 votes out of a possible 79171 registered voters. Anne Genetet - the En Marche candidate in 2017, obtained $54.11 \%$ of the vote in the first round, but because voter participation was so low (at only 22,6\%), it needed to have that majority confirmed through a second round - something that would not have been necessary had voter participation exceeded 25\%. In the second round, Genetet won with 71.72 $\%$, but again with the limited legitimacy of only 14367 votes, out of a possible 92761 registered (Ministère de l’Intérieur 2017). 
This low voter participation could trigger a crisis of political legitimacy if and when expatriateelected deputies cast deciding ballots for crucial pieces of legislation in the French Parliament. In such cases, and although 'deputies are elected to the national Assembly on a national mandate to represent 'the whole nation'” (Collard 2017), the balance of power is effectively in the hands of a few deputies elected by a very small number of expatriates, who in many cases will not be affected by the consequences of territorially-based legislation for as long as they are living abroad.

\section{Conclusion}

The significance of expatriate voting in the case of Italian and French eligible voters in Australia demonstrates a difference, in some cases a significant difference, in terms of voting behaviour than their compatriots in country. Italians in Australia in the 2016 Constitutional referendum proposals voted in favour - clearly in favour - whereas in Italy it was a definitive NO to the constitutional reforms. In the 2013 Italian elections, the vote in Australia by eligible Italian voters was to not vote for the Five Star movement and to give a stronger vote to the Mario Monti. Similarly, while French expatriate voters have rejected National Front candidates, they have systematically favoured right-leaning candidates, resulting in voting sometimes in the opposite way than their compatriots in country, while not altering the outcomes of the votes. There is also a gap between the French government's attempt to engage its expatriates in the political and electoral process, and the response of expatriates themselves. Over the years, the French government has extended right to vote for expatriates in multiple elections, but expatriate voter participation is at a record low.

Hence, there is evidence that political preferences abroad do not necessarily reflect the same electoral voting patterns in country - both in Italy and France. Those living abroad, in this case Australia, provide different political choices compared to domestic districts as the transnational community can be influenced by the political context of their host country. Whether pundits, policy makers, political parties wish to re-examine these possibilities is occurring in Italy but not in France thus far. If and when external voting ends up altering the internal result, then we would expect there would be a re-evaluation of the impact of external voting. This is still to happen. 


\section{References}

Assemblée des Français de l'Etranger, 2009, Historique, Available at http://www.assembleeafe.fr/historique,16.html, viewed 15 February 2018.

Assemblée Nationale, 2014, Rapport Visant à Instaurer le Vote par Voie Electronique des Français de L'Etranger à l'Election Présidentielle et à l'Election des Représentants au Parlement Européen, http://www.assemblee-nationale.fr/14/rapports/r2235.asp, viewed 18 February 2018.

Barry, K. 2006, Home and Away: The Construction of Citizenship in an Emigration Context, New York University Public Law and Legal Theory Working Papers.

Battiston, S \& Mascitelli, B. 2008, The challenges to democracy and citizenship surrounding the vote to Italians overseas, Modern Italy, Vol. 13, No. 3, August 2008, 261-280.

Bauböck, R. 2007, Stakeholder Citizenship and Transnational Political Participation: A Normative Evaluation of External Voting, Fordham Law Review 75, no. 5, pp. 2393-2447

Bauböck, R. 2009, The Rights and Duties of External Citizenship. Citizenship studies, vol.13, no 5: 475-499.

Béglé, J. 2017, Les Expatriés ont le même poids électoral que Paris. Le Point, http://www.lepoint.fr/presidentielle/les-expatries-ont-le-meme-poids-electoral-que-paris-0104-2017-2116460_3121.php, viewed 15 February 2019.

Belouezzane, S. 2017, Présidentielle 2017: Abstention Record pour un Second Tour depuis l’Election de 1969, Le Monde, Paris.

Brennetot, A. Colange, C. 2009, L’Expatriation Française, un Enjeu Géopolitique Emergent, M@ppemonde, 95, No. 2, pp. 1-19.

BuzzFeed 2017, The British can’t stop talking about Marine Le Pen, https://www.buzzfeed.com/albertonardelli/this-analysis-shows-how-the-british-press-isfixated-on-mari?utm_term=.asN5rWz33\#.stGxy5jQQ

Cavagna, L. 2017, Les Francais de l’Etranger ont Massivement Voté pour Emmanuel Macron, Le Figaro, Available at http://www.lefigaro.fr/elections-/presidentielles/2017/04/24/35003-20170424ARTFIG00282-les-francais-de-l-etranger-ont-massivement-vote-pouremmanuel-macron.php, viewed 15 February 2018.

Collard, S. 2013, The Expatriate Vote in the French Presidential and Legislative Elections of 2012: A Case of Unintended Consequences, Parliamentary Affairs 66, No. 1, pp. 213-233.

Consulat Général de France à Sydney 2017, Résultats du $2^{\text {nd }}$ tour des Présidentielles 2017, Available at https://au.ambafrance.org/Resultats-du-2nd-tour-des-Presidentielles-2017, viewed 15 February 2018.

Cour des Comptes 2017, Référé de la Cour des Comptes sur l’Organisation des Elections pour les Français de l'Etranger, Cour des Comptes, Available at https://www.ccomptes.fr/fr/- 
publications/lorganisation-des-elections-pour-les-francais-etablis-hors-de-france, viewed 15 February 2018.

Dehesdin, C. and Pottier, J-M. 2011, Les Legislatives des Français de l'Etranger, pas si Ingagnables pour la Gauche. Available at http://www.slate.fr/story/47327/legislativesfrancais-etranger, viewed 15 February 2018.

De Saint Sauveur, C. 2017, Macron, Héritier de Giscard, Le Parisien, Available at http://www.leparisien.fr/politique/newsletter/macron-heritier-de-giscard-19-10-20177343484.php, viewed 18 February 2018.

DW (DEUTSCHE VELLE) 2017, Why are German and Turkish relations so strained? http://www.dw.com/en/why-are-german-and-turkish-relations-so-strained/g-41232585 Consulted 29 September 2017.

Garriaud-Maylam, J., Dufoix, S., Guerassimoff, C., De Tinguy, A. 2010, Un Pays Pionnier. La Représentation Politique des Expatriés en France, Loin des Yeux, près du Cour. Les Etats et leurs Expatriés, Presses de la Fondation Nationale de Sciences Politiques, Paris, pp.105127.

Hutcheson, D. \& Arrighi, J. 2014, Keeping Pandora’s Box Half-Shut’: A Comparative Inquiry into the Institutional Limits of External Voting in EU Member States, ECPR General Conference, Glasgow (UK).

IDEA \& IFE 2007, Voting from Abroad: The International IDEA Handbook, IDEA \& IFE Stockholm and Mexico City.

IOM (International Organisation for Migration) 2010, Migration and Transnationalism : Opportunities and Challenges, 9-10 March 2010, Background paper.

King, R. 2012, Geography and Migration Studies: Retrospect and Prospect, Population, Space and Place, vol. 18. No. 2.

Lafleur, J.M. 2008, Political Transnationalism and the State., IEP Paris et Ulg: Paris et Liège.

Le Luyer, D. 2016, Citoyenneté et Appartenance Territoriale des Expatriés Français, CIST2016 Proceedings, En Quête de Territoire(s).

Levitt, P. \& de la Dehesa, R. 2003, 'Transnational Migration and the Redefinition of the State: Variations and Explanations’, Ethnic and Racial Studies, vol. 26, no.4: 587-611.

Loi Organique no 76-97 31st January 1976, Available at https://www.legifrance.gouv.fr/affichTexte.do?cidTexte=JORFTEXT000000510005\&fastPos=1\&fastReqId =707363 556\&categorieLien=id\&oldAction=rechTexte, viewed 18 February 2018.

Loi Organique no 2013-659 22 July 2013, Available at https://www.legifrance.gouv.fr/affichTexte.do?cidTexte=JORFTEXT000028056454\&fastPos =2\&fastReqId=2112975812\&categorieLien=id\&oldAction=rechTexte, viewed 18 February 2018.

Lopez-Guerra, C. 2005, 'Should Expatriates Vote?' Journal of Political Philosophy, vol.13, no2: 219-234. 
Mares, P. 2016, Not quite Australia, text publishing Melbourne, Melbourne.

Mascitelli, B., Steele R \& Battiston, S. 2013, The 2001 Italian Expatriate Vote: Was it worth it? Peter Lang, Bern.

Mascitelli, B. \& Battiston, S. 2008, The Italian Expatriate Vote in Australia. Connor Court Publishing, Ballan, Australia.

Ministère de L’Intérieur 2017, Elections, Available at https://www.interieur.gouv.fr/Elections, viewed 18 February 2018.

Ministero dell'Interno, 2017, http://elezionistorico.interno.gov.it/index.php?tpel$=\mathrm{C} \&$ dtel $=24 / 02 / 2013 \&$ tpa $=\mathrm{E} \&$ tpe $=\mathrm{A} \& \mathrm{lev} 0=0 \&$ levsut $0=0 \& \mathrm{es} 0=\mathrm{S} \& \mathrm{~ms}=\mathrm{S}$, viewed 18 February 2018.

Portes, A. 1999, 'Towards a New World - The Origin and Effects of Transnational Activities’, Ethnic and Racial Studies, vol 22, no.2: 465-477.

Quatremer, J. 2017, Emmanuel Macron, un Monarque à la Giscard plus Conservateur que Liberal, Liberation, Available at http://www.liberation.fr/politiques/2017/12/29/emmanuelmacron-un-monarque-a-la-giscard-plus-conservateur-que-liberal_1619637, viewed 18 February 2018.

Ricout, G. 1999, 'L'expatriation : les Français Etablis Hors de France, acteurs du rayonnement international de notre pays', report presented by the External Relations Department, Conseil Economique et Sociale, Paris, France.

Roudin, C. 2017, Elections, Les Français de l'Etranger votent peu et ça coûte cher, La Croix, Available at : https://www.la-croix.com/France/Politique/Elections-Francais-letranger-votentcoute-cher-2017-01-12-1200816706, viewed 18 February 2018.

Rubio-Marin, R. 2006, 'Transnational Politics and the Democratic Nation-State: Normative Challenges of Expatriate Voting and Nationality Retention of Emigrants', New York University Law Review, vol. 81, no.1: 117-147.

Sartori, G. 2004, Mala Tempora, Rioma-Bari: Editori Laterza.

Tarli, Barbieri G. 2007, Il Voto degli Italiani All'estero: Una Riforma Sbagliata. In Proporzionale ma non troppo - Le Elezioni Politiche del 2006, eds. R. D’Alimonte and A. Chiaramonte, Bologna : Il Mulino.

Vigevani, G. E. 2002, 'Il Voto All'estero: Interrogativi della "Riserva Indiana" per i Candidati’, Quaderni Costituzionali: 348-351.

Vertovec, S. 2004, 'Migrant Transationalism and Modes of Transformation', Center for Migration Studies of New York, vol. 28, no. 3: 970-1001. 
Table 1: 2013 elections - House of Deputies results for the external college Africa, Asia, Oceania and Antarctica (AAOA)

\begin{tabular}{|l|l|l|l|}
\hline Party or Electoral Coalition & Total number of vote & $\%$ of vote & Seats allocated \\
\hline Democratic Party & 14,741 & 33.16 & 1 \\
\hline With Monti for Italy & 12,872 & 28.96 & - \\
\hline People for Freedom Party & 10,103 & 22.73 & - \\
\hline Five Star Movement & 6,728 & 15.13 & \\
\hline Electoral turnout & & 30.01 & \\
\hline
\end{tabular}

Source: http://www.corriere.it/Speciali/Politica/2013/elezioni/SEAS/politiche/camera/estero/20130224000000_18_ESTERO_ES.shtml

Table 2: 2008 election - House of Deputies results for the external college Africa, Asia, Oceania and Antarctica (AAOA)

\begin{tabular}{|l|l|l|l|}
\hline Party or Electoral Coalition & Total number of vote & $\%$ of vote & Seats allocated \\
\hline Democratic Party & 21.295 & 44.66 & 1 \\
\hline People for Freedom Party & 20,533 & 43.06 & - \\
\hline Union of the Centre & 3,027 & 6.34 & - \\
\hline The Rainbow left & 1,717 & 3.6 & - \\
\hline Socialist party & 1,110 & 2.32 & - \\
\hline Electoral turnout & & 37.91 & \\
\hline
\end{tabular}

Source: http://www.corriere.it/Speciali/Politica/2013/elezioni/SEAS/politiche/camera/estero/20130224000000_18_ESTERO_ES.shtml

Table 3: Results Presidential Elections 2007, 2012 and 2017

\begin{tabular}{|c|c|c|c|c|}
\hline \multicolumn{2}{|c|}{ Presidential Election 2007 } & Australia & The world & France \\
\hline & Voters turnout (\%) & 36.3 & 55.8 & 83.8 \\
\hline
\end{tabular}




\begin{tabular}{|l|c|c|c|}
\hline Sarkozy (\%) & 55 & 54 & 53.06 \\
\hline Royale (\%) & 45 & 46 & 46.94 \\
\hline Number of voters & 3565 & 346310 & 36.7 million \\
\hline
\end{tabular}

\begin{tabular}{|l|l|c|c|c|}
\hline \multicolumn{2}{|c|}{ Presidential Election 2012 } & Australia & The world & France \\
\hline \multirow{2}{*}{} & Voters turnout (\%) & 36.5 & 48.14 & 75.68 \\
\cline { 2 - 5 } & Sarkozy (\%) & 57.08 & 57.55 & 48.36 \\
\cline { 2 - 5 } & Hollande (\%) & 42.92 & 42.45 & 51.64 \\
\cline { 2 - 5 } & Number of voters & 5247 & 380575 & 34 million \\
\hline
\end{tabular}

\begin{tabular}{|l|l|c|c|c|}
\hline \multicolumn{2}{|c|}{ Presidential Election 2017 } & Australia & The world & France \\
\hline \multirow{2}{*}{} & Voters turnout (\%) & 51.37 & 39.23 & 65.97 \\
\cline { 2 - 5 } & Macron (\%) & 89.07 & 89.31 & 66.1 \\
\cline { 2 - 5 } & Le Pen (\%) & 10.63 & 10.69 & 33.9 \\
\cline { 2 - 5 } & Number of voters & 8076 & 579954 & 31 million \\
\hline
\end{tabular}

Source: www.interieur.gouv.fr/Elections/Les-resultats/Presidentielles/elecresult_presidentielle2017/(path)/presidentielle-2017/FE.html 